\title{
Penerapan Regresi Nonparametrik Spline dalam Memodelkan Faktor- faktor yang Mempengaruhi Indeks Pembangunan Manusia di Provinsi Sulawesi Selatan Tahun 2015
}

\author{
Asmira, Muhammad Nadjib Bustan, \& Muhammad Kasim Aidid* \\ Program Studi Statistika, Fakultas Matematika dan Ilmu Pengetahuan Alam, Universitas Negeri Makassar, Indonesia
}

Keywords: Human development Index, GCV, Nonparametric

Regression Spline, Knot Points

\begin{abstract}
:
Human development index (HDI) is a measure used in monitoring and evaluating human development. Indicators used to measure HDI consists of three basic components of quality of life that is the life chances, knowledge and decent living standards. Several factors are thought to affect the HDI in the district/city in South Sulawesi province that labor force participation rates, the ratio of school pupils, overcrowding, health facilities, and the Gross Domestic Product (GDP). When HDI and these factors are plotted then shows the pattern of data that is not to follow a certain pattern, so that the data can be applied to the nonparametric regression model spline truncated. Selection of the best model seen from the point of knots and the minimum value of GCV. Based on research, the value of the minimum GCV is at three knots point is equal to 5.33 Rated amounting to $80.29 \%$.
\end{abstract}

\section{Pendahuluan}

Indeks Pembangunan Manusia (IPM) diperkenalkan pertama kali oleh United Nations Development Programme (UNDP) pada tahun 1990. IPM merupakan sebuah ukuran yang digunakan dalam memantau dan mengevaluasi pembangunan manusia. Indikator yang digunakan untuk mengukur IPM terdiri dari tiga komponen dasar kualitas hidup manusia yaitu peluang hidup (longevity), pengetahuan (knowledge) dan standar hidup layak (decent living). IPM di Sulawesi Selatan tahun 2015 tercatat sebesar 69,15, meningkat dibanding tahun sebelumnya sebesar 68,49. Sepanjang periode tahun 2010-2015 IPM terus meningkat. Meski meningkat, namun tidak tertutup kemungkinan nilainya akan menurun tergantung dari pergerakan masing-masing peubah yang mempengaruhi.

Karena nilai peubah penyusun IPM yang tidak menentu maka hal ini menjadi krusial untuk diteliti. Untuk mengetahui faktor-faktor yang diduga mempengaruhi IPM, umumnya digunakan analisis regresi klasik. Namun untuk data IPM di Provinsi Sulawesi Selatan tahun 2015 tidak cocok digunakan dalam analisis regresi klasik karena data menunjukan bentuk pola hubungan antara IPM dengan peubah yang diduga mempengaruhinya tidak memiliki pola tertentu sehingga menggunakan metode regresi nonparametrik. Menurut Hardle (1990) metode yang dapat digunakan untuk mengatasi masalah dalam model regresi nonparametrik yaitu Spline. Spline mempunyai keunggulan dalam mengatasi pola data yang bersifat tidak mengikuti pola tertentu, yang menunjukan naik atau turun yang tajam dengan dengan bantuan titik-titik knot, serta kurva yang dihasilkan relative mulus.

Hal ini sejalan dengan beberapa penelitian sebelumnya yang dilakukan oleh Kornelius (2016) dikatakan bahwa data IPM di Indonesia dapat diterapkan pada model regresi nonparametrik spline truncated. Pada tahun yang sama,

\footnotetext{
* Corresponding author.

E-mail address: kasimaidid@unm.ac.id
} 
penelitian juga dilakukakn oleh Yanthi (2016) dan dihasilkan bahwa model regresi nonparametrik spline terbaik untuk pemodelan IPM di Jawa Tengah adalah dengan menggunakan kombinasi titik knot. Berdasarkan penjelasan diatas, maka dilakukan penelitian tentang penerapan regresi nonparametrik Spline dalam memodelkan faktor-faktor yang mempengaruhi IPM kabupaten/kota di Provinsi Sulawesi Selatan tahun 2015. Dalam menentukan model regresi nonparametrik spline terbaik ada beberapa hal yang perlu dilakukan yaitu menentukan letak titik knot dan jumlah titik knot. Untuk memilih model spline terbaik dilihat dari nilai GCV minimum.

\section{Tinjauan Pustaka}

\subsection{Regresi Nonparametrik Spline}

Regresi nonparametrik disebut juga statistik sebaran bebas. Statistik nonparametrik tidak mensyaratkan bentuk sebaran dari populasinya sehingga dapat diaplikasikan untuk data baik yang menyebar normal maupun tidak. Regresi nonparametrik adalah suatu metode pemodelan yang tidak terikat akan asumsiasumsi dari persamaan regresi tertentu yang memberikan fleksibilitas yang tinggi dalam menduga sebuah model. Regresi nonparametrik juga merupakan suatu metode statistika yang digunakan untuk mengetahui hubungan peubah tak bebas dan peubah bebas yang tidak diketahui bentuk fungsinya, hanya diasumsikan smooth (mulus) dalam arti termuat dalam suatu ruang fungsi tertentu, sehingga regresi nonparametrik sangat memperhatikan fleksibilitasnya (Eubank, 1988).

Pendekatan regresi nonparametrik yang banyak digunakan adalah spline truncated. Spline truncated merupakan potongan-potongan polinomial yang emiliki sifat tersegmen dan kontinu. Salah satu kelebihan spline truncated adalah mempunyai sifat fleksibilitas yang tinggi dan cenderung mencari sendiri estimasi data kemanapun pola data tersebut bergerak. Kemampuan mengestimasi perilaku data ini ditunjukkan oleh fungsi truncated (potongan-potongan) yang melekat pada estimator dan potongan-potongan tersebut yang disebut titik knot.

Spline merupakan salah satu jenis piecewise polinomial, yaitu polinomial yang memiliki sifat tersegmen. Sifat tersegmen ini memberikan fleksibilitas yang lebih baik dari polinomial biasa, sehingga memungkinkan untuk menyesuaikan diri secara lebih efektif terhadap karakteristik lokal suatu fungsi atau data. Spline mempunyai keunggulan dalam mengatasi pola data yang menunjukan naik atau turun yang tajam dengan dengan bantuan titiktitik knot, serta kurva yang dihasilkan relative mulus (Hẳrdle, 1990). Secara umum, fungsi spline truncated dengan derajat $m$ dan titik-titik knot $\lambda_{1}, \lambda_{2}, \ldots, \lambda_{\mathrm{m}}$ adalah suatu fungsi yang dapat ditulis dalam bentuk persamaan:

$$
\begin{aligned}
y_{i} & =f\left(x_{i}\right)+\varepsilon_{i}, \quad i=1,2,3, \ldots, n \\
& =\sum_{j=0}^{m} \beta_{j} x^{j}+\sum_{k=1}^{K} \beta_{k+q}\left(x-\lambda_{k}\right)_{+}^{m}+\varepsilon_{i}
\end{aligned}
$$

Dengan fungsi sepenggal (truncated) sebagai berikut:

$$
(x-\lambda)_{+}^{m}= \begin{cases}(x-\lambda)^{m} & , x \geq \lambda \\ 0 & , x \leq \lambda\end{cases}
$$

Dimana adalah peubah respon, peubah prediktor, ( ) adalah fungsi regresi yang tidak mengikuti pola tertentu, dan adalah error acak yang diasumsikan identik, independen, dan berdistribusi normal dengan mean nol dan variansi (Wahba, 1990). Sebagai salah satu ilustrasi sederhana diberikan spline linear truncated dengan tiga titik knot pada $x_{1}$ $=\lambda_{1} \leq x_{2}=\lambda_{2} \leq x_{3}=\lambda_{3}$ diberikan oleh:

$$
f_{1}(x)=\beta_{0}+\beta_{1} x+\beta_{2}\left(x-\lambda_{1}\right)_{+}^{1}+\beta_{3}\left(x-\lambda_{2}\right)_{+}^{1}+\beta_{4}\left(x-\lambda_{3}\right)_{+}^{1}
$$

Fungsi spline $f_{1}(x)$ dapat disajikan dalam bentuk:

$$
f_{1}(x)=\left\{\begin{array}{cc}
\beta_{0}+\beta_{1} x & , x<\lambda_{1} \\
\beta_{0}+\beta_{1} x+\beta_{2}\left(x-\lambda_{1}\right) & , \lambda_{1} \leq x \leq \lambda_{2} \\
\beta_{0}+\beta_{1} x+\beta_{2}\left(x-\lambda_{1}\right)_{+}^{1}+\beta_{3}\left(x-\lambda_{2}\right) & , \lambda_{2} \leq x \leq \lambda_{3} \\
\beta_{0}+\beta_{1} x+\beta_{2}\left(x-\lambda_{1}\right)_{+}^{1}+\beta_{3}\left(x-\lambda_{2}\right)_{+}^{1}+\beta_{4}\left(x-\lambda_{3}\right), x \geq \lambda_{3}
\end{array}\right.
$$




\subsection{Indeks Pembangunan Manusia}

Indeks Pembangunan Manusia (IPM) diperkenalkan pertama kali oleh United Nations Development Programme (UNDP) pada tahun 1990. Indikator pembangunan manusia merupakan salah satu alat ukur yang dapat digunakan untuk menilai kualitas pembangunan manusia, baik dari sisi dampaknya terhadap kondisi fisik manusia (kesehatan dan kesejahteraan) maupun yang bersifat non-fisik (intelektualitas). IPM merupakan indikator strategis yang banyak digunakan untuk melihat upaya dan kinerja program pembangunan secara menyeluruh di suatu wilayah. Dalam hal ini IPM dianggap sebagai gambaran dari hasil program pembangunan yang telah dilakukan beberapa tahun sebelumnya.

IPM mencakup tiga komponen yang dianggap mendasar bagi manusia dan secara operasional mudah dihitung untuk menghasilkan suatu ukuran yang merefleksikan upaya pembangunan manusia. Ketiga komponen tersebut adalah peluang hidup (longevity), pengetahuan (knowledge) dan standar hidup layak (living standards). Dari ketiga komponen tersebut memiliki pengertian yang sangat luas karena terkait banyak faktor. Dalam penelitian ini untuk mengukur dimensi kesehatan, digunakan indikator fasilitas kesehatan. Selanjutnya untuk mengukur dimensi pengetahuan digunakan indikator rasio sekolah murid. Adapun untuk mengukur dimensi standar hidup layak digunakan gabungan indikator kepadatan penduduk, partisipasi angkatan kerja dan PDRB per tahun.

Capaian pembangunan manusia di suatu wilayah pada waktu tertentu dapat dikelompokkan ke dalam empat kelompok. Pengelompokan ini bertujuan untuk mengorganisasikan wilayah-wilayah menjadi kelompok-kelompok yang sama dalam hal pembangunan manusia.
a) Sangat Tinggi : IPM $\geq 80$
b) Tinggi : $70 \leq$ IPM $<80$
c) Sedang : $60 \leq$ IPM $<70$
d) Rendah : IPM $<60$

Rumus umum yang digunakan untuk menghitung IPM adalah sebagai berikut (UNDP, 2004):

$$
\mathrm{IPM}=\frac{1}{3}\left(Y_{1}+Y_{2}+Y_{2}\right)
$$

Keterangan:

IPM = Indeks Pembangunan Manusia,

$\mathrm{Y}_{1}=$ Indeks harapan hidup,

$\mathrm{Y}_{2}=$ Indeks pendidikan,

$\mathrm{Y}_{3}=$ Indeks standar hidup layak.

\section{Metode Penelitian}

Sumber data yang digunakan dalam penelitian ini adalah data sekunder yang dipublikasikan oleh Badan Pusat Statistik (BPS). Adapun peubah respon yang digunakan adalah IPM kabupaten/kota di Provinsi Sulawesi Selatan tahun 2015. Sedangkan peubah penjelas yang diduga mempengaruhi pertumbuhan IPM yaitu tingkat partisipasi angkatan kerja (TPAK), rasio sekolah murid (RSM), kepadatan penduduk, fasilitas kesehatan, dan PDRB. Obyek dari penelitian ini adalah 24 kabupaten/kota di Provinsi Sulawesi Selatan, yang terdiri dari 3 kota dan 21 kabupaten.

Adapun definisi dari peubah yang digunakan adalah:

1) Indeks Pembangunan Manusia (IPM)

IPM adalah nilai komposit dari pada pembangunan manusia yang dihitung dalam tiga komponen yaitu peluang hidup (longevity), pengetahuan (knowledge) dan standar hidup layak (living standards). 


\section{2) Tingkat Partisipasi Angkatan Kerja (TPAK)}

TPAK adalah rasio angkatan kerja dengan jumlah penduduk. Dengan kata lain yaitu besarnya jumlah penduduk yang masuk dalam pasar kerja. Badan pusat statistik mendefinisikan angkatan kerja sebagi penduduk usia kerja (berusia 15 tahun ke atas) termasuk bekerja dan mencari pekerjaan.

3) Rasio Sekolah Murid (RSM)

RSM yaitu rata-rata jumlah siswa yang dapat belajar disuatu sekolah, yaitu Sekolah Menengah Atas (SMA).

4) Kepadatan Penduduk

Kepadatan penduduk adalah rasio banyaknya penduduk persatuan luas. Kegunaannya adalah sebagai dasar kebijakan pemerataan penduduk dalam program transmigrasi.

5) Fasilitas Kesehatan

Fasilitas kesehatan dalam hal ini adalah jumlah puskesmas (Public Health Center), Puskesmas pembantu (public health sub center), puskesmas keliling (Mobile Public Health Center), dan Posyandu (Maternal \& Child Health center).

6) Produk Domestik Regional Bruto (PDRB)

PDRB menggambarkan kemampuan suatu wilayah untuk menciptakan nilai tambah pada suatu waktu tertentu (satu tahun). PDRB menggunakan dua pendekatan yaitu lapangan usaha dan pengeluaran.

\section{Hasil dan Pembahasan}

\subsection{Analisis Pola Hubungan Faktor-Faktor yang Diduga Mempengaruhi IPM Kabupaten/kota di Provinsi Sulawesi Selatan}

Pada Gambar 1 diketahui bahwa antara peubah TPAK ( $\left.X_{1}\right)$ dengan IPM menunjukkan pola hubungan yang tidak membentuk suatu pola tertentu, sehingga estimasi model menggunakan regresi nonparametrik.

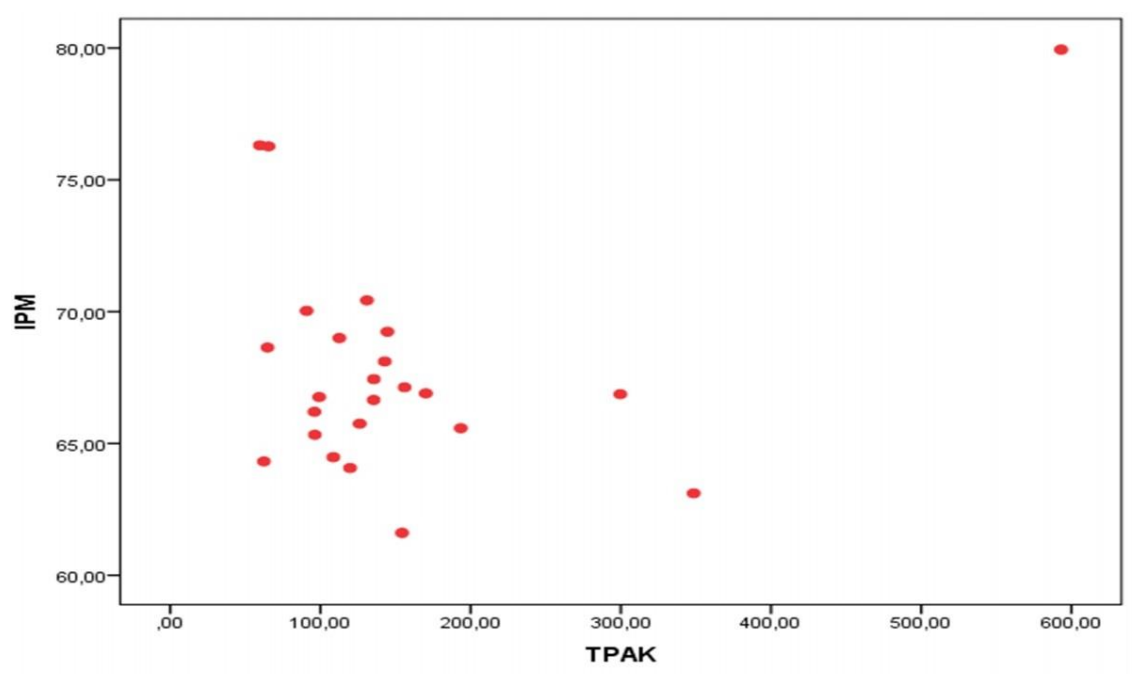

Gambar 1 Pola hubungan TPAK dengan IPM kabupaten/kota di Provinsi Sulawesi Selatan tahun 2015 


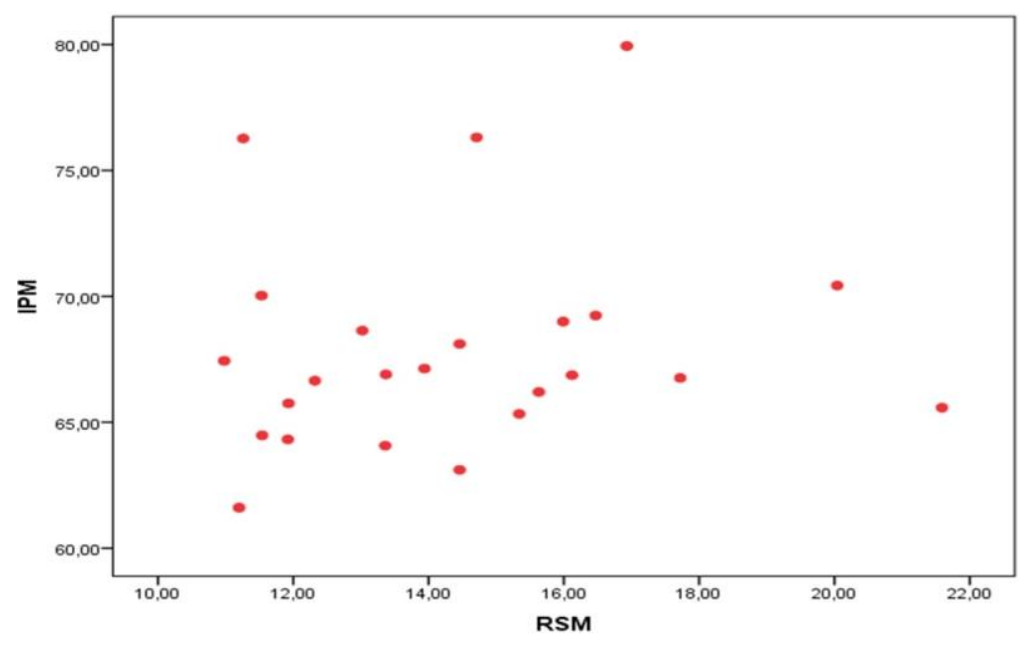

Gambar 2 Pola hubungan RSM dengan IPM kabupaten/kota di Provinsi Sulawesi Selatan tahun 2015

Pola hubungan antara peubah RSM (X2) dengan IPM yang disajikan pada Gambar 2 menunjukkan pola hubungan yang tidak membentuk suatu pola tertentu, sehingga estimasi model yang digunakan adalah regresi nonparametrik.

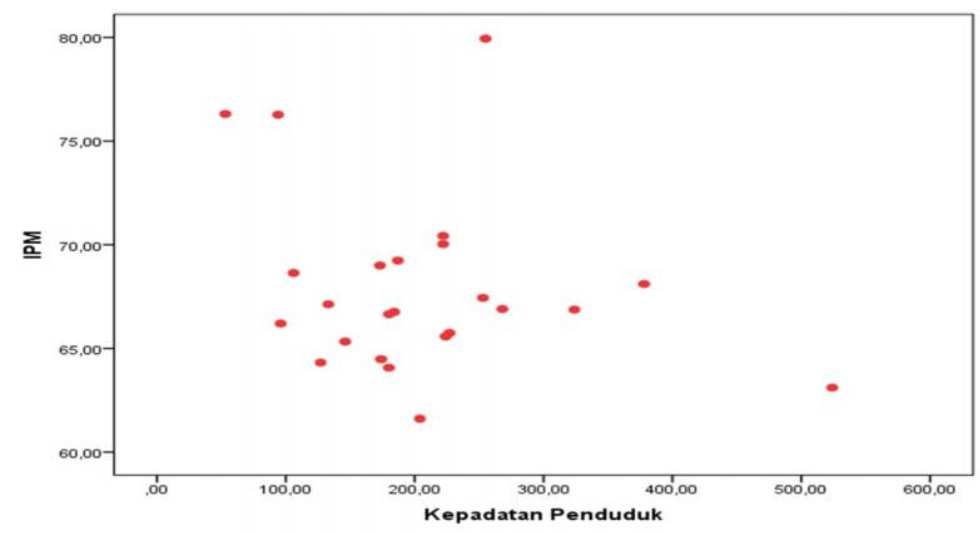

Gambar 3 Pola hubungan Kepadatan Penduduk dengan IPM kabupaten/kota di Provinsi Sulawesi Selatan tahun 2015

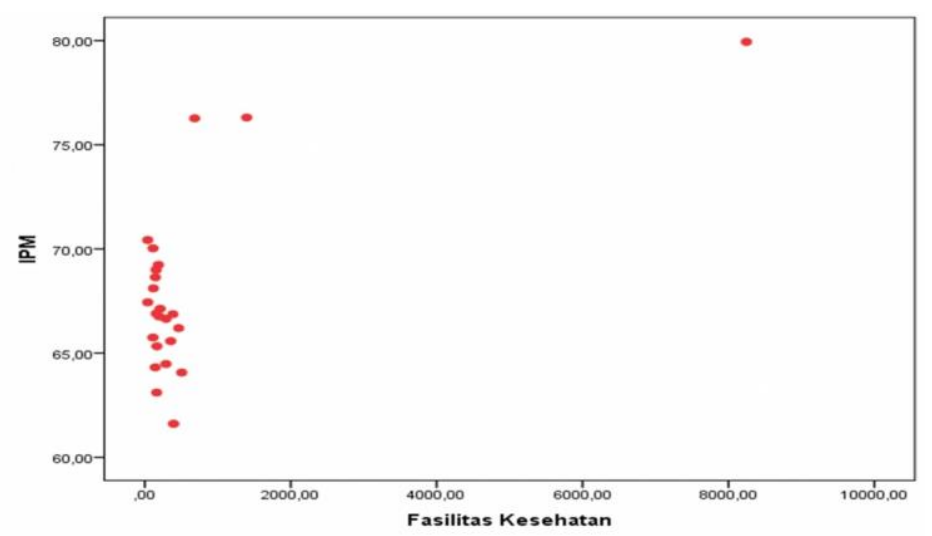

Gambar 4 Pola hubungan Fasilitas Kesehatan dengan IPM kabupaten/kota di Provinsi Sulawesi Selatan tahun 2015 


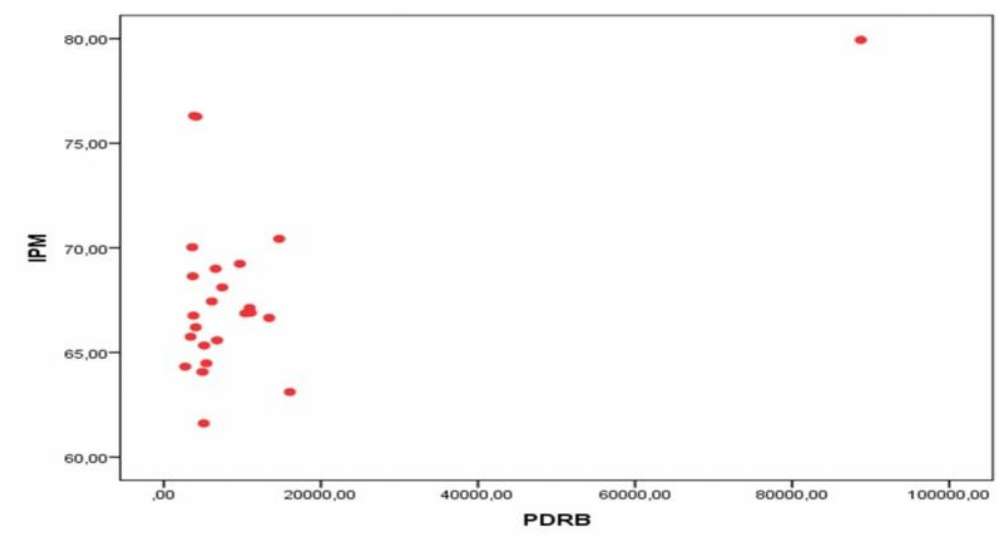

Gambar 5 Pola hubungan PDRB dengan IPM kabupaten/kota di Provinsi Sulawesi Selatan tahun 2015

Pada Gambar 3 diketahui bahwa antara peubah Kepadatan Penduduk (X3) dengan IPM menunjukan pola hubungan yang tidak membentuk suatu pola tertentu, sehingga estimasi model menggunakan regresi nonparametrik. Pola hubungan antara peubah Fasilitas Kesehatan (X4) dengan IPM yang disajikan pada Gambar 4 menunjukkan pola hubungan yang tidak membentuk suatu pola tertentu, sehingga estimasi model yang digunakan adalah regresi nonparametrik. Berdasarkan Gambar 5 diketahui bahwa antara peubah PDRB (X5) dengan IPM mempunyai pola hubungan IPM yang tidak membentuk suatu pola tertentu, sehingga estimasi model yang digunakan adalah regresi nonparametrik.

\subsection{Pemilihan Titik Knot Optimum}

Titik knot merupakan titik perubahan perilaku data pad sub-sub interval tertentu. Model regresi nonparametrik spline terbaik didapatkan dari titik knot optimal, yaitu dengan menggunakan metode Generalized Cross Validition (GCV). Nilai GCV yang paling minimum merupakan titik knot yang optimal. Pemilihan titik knot optimal dengan satu titik knot, dua titik knot, dan tiga titik knot dijelaskan sebagai berikut.

\subsubsection{Pemilihan titik knot dengan satu titik knot}

Estimasi model regresi nonparametrik spline dengan satu titik knot pada angka IPM di Sulawesi Selatan adalah sebagai berikut.

$$
\begin{aligned}
\hat{y}= & \hat{\beta}_{0}+\hat{\beta}_{1} x_{1}+\hat{\beta}_{2}\left(x_{1}-\lambda_{1}\right)_{+}^{1}+\hat{\beta}_{3} x_{2}+\hat{\beta}_{4}\left(x_{2}-\lambda_{2}\right)_{+}^{1}+\hat{\beta}_{5} x_{3}+ \\
& \hat{\beta}_{6}\left(x_{3}-\lambda_{3}\right)_{+}^{1}+\hat{\beta}_{7} x_{4}+\hat{\beta}_{9}\left(x_{4}-\lambda_{4}\right)_{+}^{1}+\hat{\beta}_{\mathrm{g}} x_{5}+\hat{\beta}_{1}\left(x_{5}-\lambda_{5}\right)_{+}^{1}
\end{aligned}
$$

Berdasarkan Tabel 1 diketahui bahwa nilai GCV minumum untuk model regresi nonparametrik spline dengan satu titik knot adalah 12,42 nilai tersebut diperoleh dari satu titik knot optimal pada setiap peubah prediktor. Titik knot optimal untuk peubah TPAK (X1) berada pada titik knot 59,66; peubah RSM (X2) berada pada titik knot 10,98; peubah Kepadatan Penduduk (X3) berada pada titik knot 40,00; peubah Fasilitas Kesehatan (X4) berada pada titik knot 53,00; dan peubah PDRB (X5) berada pada titik knot 2723,81.

Tabel 1 Nilai GCV satu titik knot

\begin{tabular}{cccccc}
\hline $\mathbf{X 1}$ & $\mathbf{X 2}$ & $\mathbf{X 3}$ & $\mathbf{X 4}$ & $\mathbf{X 5}$ & $\mathbf{G C V}$ \\
\hline 59,66 & 10,98 & 40,00 & 53,00 & 2723,81 & 30,91 \\
70,54 & 11,19 & 207,47 & 62,61 & 4479,25 & 55,80 \\
81,43 & 11,41 & 374,94 & 72,22 & 6234,68 & 41,50 \\
92,32 & 11,63 & 542,41 & 81,84 & 7990,12 & 35,77 \\
\hline
\end{tabular}




\begin{tabular}{cccccc}
\hline $\mathbf{X 1}$ & $\mathbf{X 2}$ & $\mathbf{X 3}$ & $\mathbf{X 4}$ & $\mathbf{X 5}$ & $\mathbf{G C V}$ \\
\hline 103,21 & 11,85 & 709,87 & 91,45 & 9745,55 & 46,70 \\
114,09 & 12,06 & 877,35 & 101,06 & 11500,99 & 57,81 \\
124,98 & 12,28 & 1044,82 & 110,67 & 13256,43 & 76,62 \\
135,87 & 12,49 & 1212,29 & 120,29 & 15011,87 & 100,37 \\
146,76 & 12,71 & 1379,76 & 129,89 & 16767,30 & 124,36 \\
157,65 & 12,93 & 1547,22 & 139,51 & 18522,74 & 148,36 \\
\hline
\end{tabular}

Adapun model regresi nonparametrik spline dengan satu titik knot yaitu:

$$
\begin{gathered}
y=3,07+9,91 x_{1}+6,79\left(x_{1}-59,66\right)_{+}^{1}+6,84 x_{2}-7,27\left(x_{2}-10,98\right)_{+}^{1}- \\
9,95 x_{3}+1,023\left(x_{3}-40,00\right)_{+}^{1}+3,21 x_{4}+5,46\left(x_{4}-53,00\right)_{+}^{1}- \\
5,50 x_{5}+8,59\left(x_{5}-2723,81\right)_{+}^{1}
\end{gathered}
$$

4.2.2. Pemilihan titik knot dengan dua titik knot

$$
\begin{aligned}
\hat{y}=\beta_{0}+ & \beta_{1} x_{1}+\beta_{2}\left(x_{1}-\lambda_{1}\right)_{+}^{1}+\beta_{3}\left(x_{1}-\lambda_{2}\right)_{+}^{1}+ \\
& \hat{\beta}_{4} x_{2}+\hat{\beta}_{5}\left(x_{2}-\lambda_{3}\right)_{+}^{1}+\hat{\beta}_{6}\left(x_{2}-\lambda_{4}\right)_{+}^{1}+ \\
& \beta_{7} x_{3}+\beta_{8}\left(x_{3}-\lambda_{5}\right)_{+}^{1}+\beta_{9}\left(x_{3}-\lambda_{6}\right)_{+}^{1}+ \\
& \hat{\beta}_{1} x_{4}+\hat{\beta}_{1}\left(x_{4}-\lambda_{7}\right)_{+}^{1}+\hat{\beta}_{1}\left(x_{4}-\lambda_{4}\right)_{+}^{1}+ \\
& \beta_{1} x_{5}+\beta_{1}\left(x_{5}-\lambda_{9}\right)_{+}^{1}+\beta_{1}\left(x_{5}-\lambda_{1}\right)_{+}^{1}
\end{aligned}
$$

Tabel 2 menunjukan sepuluh nilai GCV yang berada disekitar nilai GCV paling minimum untuk model regresi nonparametrik spline dengan dua titik knot adalah sebesar 6,91. nilai tersebut diperoleh dari dua titik knot optimal pada setiap peubah prediktor. Titik knot optimal untuk peubah TPAK kerja (X1) berada pada titik knot 92,32 dan 114,09; peubah RSM (X2) berada pada titik knot 11,63dan 12,06; peubah Kepadatan Penduduk (X3) berada pada titik knot 542,41 dan 877,35; peubah Fasilitas Kesehatan (X4) berada pada titik knot 81,84 dan 101,06; dan peubah PDRB (X5) berada pada titik knot 7990,12 dan 11500,99.

Adapun model regresi nonparametrik spline dengan dua titik knot yaitu:

$$
\begin{aligned}
\hat{y}=3,07+ & 9,91 x_{1}+6,79\left(x_{1}-92,32\right)_{+}^{1}+6,84\left(x_{1}-114,09\right)_{+}^{1}- \\
& 7,23 x_{2}-9,95\left(x_{2}-11,63\right)_{+}^{1}+1,02\left(x_{2}-12,06\right)_{+}^{1}+3,21 \\
& \left(x_{2}-12,06\right)_{+}^{1}+5,46 x_{3}+5,50\left(x_{3}-542,41\right)_{+}^{1}+5,59 \\
& \left(x_{3}-877,35\right)_{+}^{1}-1,12 x_{4}+1,58\left(x_{4}-81,84\right)_{+}^{1}-2,27 \\
& \left(x_{4}-101,06\right)_{+}^{1}+2,03 x_{5}+0,00\left(x_{5}-7990,12\right)_{+}^{1}-4,05 \\
& \left(x_{5}-11500,99\right)_{+}^{1}
\end{aligned}
$$


Tabel 2 Nilai GCV dua titik knot

\begin{tabular}{ccrrrl}
\hline $\boldsymbol{X}_{\mathbf{1}}$ & $\boldsymbol{X}_{\mathbf{2}}$ & $\boldsymbol{X}_{\mathbf{3}}$ & $\boldsymbol{X}_{\mathbf{4}}$ & \multicolumn{1}{c}{$\boldsymbol{X}_{\mathbf{5}}$} & $\mathbf{G C V}$ \\
\hline 59,65 & 10,98 & 40,00 & 53,00 & 2723,81 & \multirow{2}{*}{15,70} \\
70,55 & 11,19 & 207,47 & 62,61 & 4479,25 & \\
59,66 & 10,98 & 40,00 & 53,00 & 2723,81 & 13,23 \\
81,43 & 11,41 & 374,94 & 72,22 & 6234,68 & \\
59,66 & 10,98 & 40,00 & 53,00 & 2723,81 & 12,10 \\
92,32 & 11,63 & 542,41 & 81,84 & 7990,12 & \\
59,66 & 10,98 & 40,00 & 53,00 & 2723,81 & 10,97 \\
103,21 & 11,85 & 709,88 & 91,45 & 9745,56 & \\
59,66 & 10,98 & 40,00 & 53,00 & 2723,81 & 11,10 \\
114,09 & 12,06 & 877,35 & 101,06 & 11500,99 & \\
59,66 & 10,98 & 40,00 & 53,00 & 2723,81 & 11,50 \\
124,98 & 12,28 & 1044,82 & 110,67 & 13256,43 & \\
59,66 & 10,98 & 40,00 & 53,00 & 2723,81 & 13,08 \\
135,87 & 12,49 & 1212,26 & 120,29 & 15011,87 & \\
59,66 & 10,98 & 40,00 & 53,00 & 2723,81 & 11,76 \\
146,76 & 12,71 & 1379,76 & 129,89 & 16767,304 & \\
$\vdots$ & $\vdots$ & $\vdots$ & $\vdots$ & $\vdots$ & \\
92,32 & 11,63 & 542,41 & 81,84 & 7990,120 & \multirow{6}{*}{, 45} \\
114,09 & 12,06 & 877,35 & 101,06 & 11500,99 & \\
\hline & & & & &
\end{tabular}

4.2.3. Pemilihan titik knot dengan tiga titik knot

$$
\begin{aligned}
y= & \hat{\beta}_{0}+\hat{\beta}_{1} x_{1}+\hat{\beta}_{2}\left(x_{1}-\lambda_{1}\right)_{+}^{1}+\hat{\beta}_{3}\left(x_{1}-\lambda_{2}\right)_{+}^{1}+\hat{\beta}_{4}\left(x_{1}-\lambda_{3}\right)_{+}^{1}+ \\
& \beta_{5} x_{2}+\beta_{6}\left(x_{2}-\lambda_{4}\right)_{+}^{1}+\beta_{7}\left(x_{2}-\lambda_{5}\right)_{+}^{1}+\beta_{8}\left(x_{2}-\lambda_{6}\right)_{+}^{1}+ \\
& \beta_{9} x_{3}+\beta_{1}\left(x_{3}-\lambda_{7}\right)_{+}^{1}+\beta_{1}\left(x_{3}-\lambda_{8}\right)_{+}^{1}+\beta_{1}\left(x_{3}-\lambda_{9}\right)_{+}^{1}+\beta_{1} x_{4}+ \\
& \hat{\beta}_{1}\left(x_{4}-\lambda_{1}\right)_{+}^{1}+\hat{\beta}_{1}\left(x_{4}-\lambda_{1}\right)_{+}^{1}+\hat{\beta}_{1}\left(x_{4}-\lambda_{1}\right)_{+}^{1}+ \\
& \beta_{1} x_{5}+\beta_{1}\left(x_{5}-\lambda_{1}\right)_{+}^{1}+\beta_{1}\left(x_{5}-\lambda_{1}\right)_{+}^{1}+\beta_{2}\left(x_{5}-\lambda_{1}\right)_{+}^{1}
\end{aligned}
$$

Pada Tabel 3 diketahui bahwa nilai GCV minimum untuk model regresi nonparametrik spline dengan tiga titik knot adalah sebesar 5,33. Nilai tersebut diperoleh dari tiga titik knot optimal pada setiap peubah prediktor. Titik knot optimal untuk peubah TPAK $\left(\mathrm{X}_{1}\right)$ berada pada titik knot 92,32; 103,21; dan 538,72. RSM $\left(\mathrm{X}_{2}\right)$ berada pada titik knot 11,63; 11,84612; dan 21,37, peubah Kepadatan Penduduk $\left(\mathrm{X}_{3}\right)$ berada pada titik knot 542,41; 709,88; dan 8078,53, peubah Fasilitas Kesehatan $\left(\mathrm{X}_{4}\right)$ berada pada titik knot 81,84; 91,45; dan 475,94, dan peubah PDRB $\left(\mathrm{X}_{5}\right)$ berada pada titik knot 7990,12; 9745,56; dan 79963,03. 
Tabel 3 Nilai GCV tiga titik knot

\begin{tabular}{cccccc}
\hline $\boldsymbol{X}_{\mathbf{1}}$ & $\boldsymbol{X}_{\mathbf{Z}}$ & $\boldsymbol{X}_{\mathbf{3}}$ & $\boldsymbol{X}_{\mathbf{4}}$ & $\boldsymbol{X}_{\mathbf{5}}$ & $\mathbf{G C V}$ \\
\hline 70,55 & 11,19 & 207,47 & 62,61 & 4479,25 & \\
81,43 & 11,41 & 374,94 & 72,22 & 6234,69 & 23,38 \\
92,32 & 11,63 & 542,41 & 81,84 & 7990,12 & \\
70,55 & 11,19 & 207,47 & 62,61 & 4479,25 & \\
81,43 & 11,41 & 374,94 & 72,22 & 6234,68 & 18,52 \\
103,21 & 11,85 & 709,88 & 91,45 & 9745,56 & \\
70,55 & 11,19 & 207,47 & 62,61 & 4479,25 & \\
81,43 & 11,41 & 374,94 & 72,22 & 6234,68 & 11,30 \\
114,09 & 12,06 & 877,35 & 101,06 & 11500,99 & \\
70,55 & 11,19 & 207,47 & 62,61 & 4479,25 & \\
81,43 & 11,41 & 374,94 & 72,22 & 6234,69 & 15,01 \\
124,98 & 12,28 & 1044,82 & 110,67 & 13256,43 & \\
53,25 & 11,19 & 207,47 & 62,61 & 4479,25 & \\
81,43 & 11,41 & 374,94 & 72,22 & 6234,68 & 39,10 \\
135,87 & 12,49 & 1212,29 & 120,29 & 15011,87 & \\
53,25 & 11,19 & 207,47 & 62,61 & 4479,25 & \\
81,43 & 11,41 & 374,94 & 72,22 & 6234,68 & 56,81 \\
146,76 & 12,71 & 1379,76 & 129,89 & 16767,31 & \\
$\vdots$ & $\vdots$ & $\vdots$ & $\vdots$ & $\vdots$ & \\
92,32 & 11,63 & 542,41 & 81,84 & 7990,12 & \\
103,21 & 11,83 & 709,88 & 91,45 & 9745,56 & $\mathbf{5 , 3 3}$ \\
538,72 & 21,37 & 7408,66 & 475,94 & 79963,03 & \\
\hline & & & & &
\end{tabular}

Adapun model regresi nonparametrik spline dengan tiga titik knot yaitu:

$$
\begin{aligned}
\hat{y}=3,06 & +9,91 x_{1}+6,79\left(x_{1}-92,32\right)_{+}^{1}+6,84\left(x_{1}-103,21\right)_{+}^{1}- \\
& 7,23\left(x_{1}-538,72\right)_{+}^{1}-9,95 x_{2}+1,02\left(x_{2}-11,63\right)_{+}^{1}+3,21 \\
& \left(x_{2}-11,85\right)_{+}^{1}+5,46\left(x_{2}-21,37\right)_{+}^{1}+5,50 x_{3}+8,59 \\
& \left(x_{3}-542,41\right)_{+}^{1}-1,12\left(x_{3}-709,88\right)_{+}^{1}+1,58\left(x_{3}-7408,65\right)_{+}^{1} \\
& -2,27 x_{4}+2,03\left(x_{4}-81,84\right)_{+}^{1}+0,00\left(x_{4}-91,45\right)_{+}^{1}-4,05 \\
& \left(x_{4}-514,39\right)_{+}^{1}-4,13 x_{5}-1,95\left(x_{5}-7990,12\right)_{+}^{1}-2,13 \\
& \left(x_{5}-9745,56\right)_{+}^{1}-4,20\left(x_{5}-79963,03\right)_{+}^{1}
\end{aligned}
$$

\subsubsection{Pemilihan titik knot terbaik}

Titik knot terbaik merupakan titik knot yang mempunyai nilai GCV minimum. Berikut perbandingan nilai GCV minimum diperoleh pada satu titik knot, dua titik knot, tiga titik knot yang ditunjukan pada Tabel 4 pada tabel tersebut diketahui bahwa nilai GCV paling minimum adalah regresi nonparametrik spline menggunakan tiga titik knot yaitu sebesar 6,04. 
Tabel 4 Perbandingan nilai GCV

\begin{tabular}{cc}
\hline Model & GCV \\
\hline 1 Titik knot & 30,91 \\
2 Titik Knot & 6,45 \\
3 Titik Knot & 5,33 \\
\hline
\end{tabular}

Berdasarkan Kriteria pemilihan model terbaik diketahui bahwa nilai GCV paling minimum dihasilkan oleh model regresi nonparametrik spline dengan tiga titik knot. Berikut merupakan model regresi Nonparametrik Spline terbaik untuk dilakukan estimasi peubah menggunakan Maxsimum Likelihood Estimasi (MLE).

\subsection{Pengujian Signifikansi Peubah Model Regresi Nonparametrik Spline}

Setelah didapatkan model regresi nonparametrik spline terbaik, kemudian dilakukan pengujian signifikansi peubah regresi nonparametrik spline. Pengujian ini dilakukan untuk mengetahui faktor-faktor yang signifikan mempengaruhi IPM kabupaten/kota di Provinsi Sulawesi Selatan tahun 2015. Pengujian dilakukan secara serentak dan individu. Apabila hasil pengujian serentak menunjukkan terdapat minimal satu peubah yang signifikan, maka dilanjutkan pada pengujian secara individu.

\subsubsection{Pengujian serentak}

Tujuan pengujian secara serentak adalah mengetahui signifikansi peubah dalam model secara keseluruhan. Pengujian hipotesis untuk menguji signifikansi peubah secara serentak menggunakan hipotesis sebagai berikut:

$H_{0}: \beta_{1}=\beta_{2}=\cdots=\beta_{2}=0$

$H_{1}$ : paling sedikit terdapat $\beta_{h} \neq 0$; di $\quad h=1,2, \ldots, 20$

Berikut merupakan analisis ragam uji serentak dari model regresi nonparametrik spline yang disajikan pada Table 5.

Tabel 5 Analisis Ragam Uji Serentak

\begin{tabular}{llllcr}
\hline $\begin{array}{l}\text { Sumber } \\
\text { Variasi }\end{array}$ & $\begin{array}{l}\text { Derajat } \\
\text { Bebas } \\
(\mathrm{db})\end{array}$ & $\begin{array}{l}\text { Jumlah } \\
\text { Kuadrat } \\
(\mathrm{JK})\end{array}$ & $\begin{array}{l}\text { Rataan } \\
\text { jumlah } \\
\text { Kuadrat } \\
(\mathrm{RJK})\end{array}$ & F_hitung & p-value \\
\hline Regression & 20 & 1747,93 & 87,39 & 0,17 & 0,99 \\
Residual & 3 & 1525,16 & 508,37 & & \\
Total & 23 & 3273,05 & & & \\
\hline
\end{tabular}

Berdasarkan Tabel 5 diperoleh nilai statistik uji $\mathrm{F}$ sebesar 0,17 dengan p-value sebesar 0,99 pada tingkat signifikan ( $\alpha$ ) 5\%. Nilai p-value libih besar dari $\alpha$ sehingga $\mathrm{H}_{0}$ gagal tolak. Hal ini menunjukan bahwa semua peubah prediktor tidak berpengaruh secara signifikan terhadap nilai IPM.

\subsubsection{Pengujian parsial/individu}

Hasil pengujian secara serentak menunjukan bahwa minimal terdapat satu peubah dari model regresi nonparametrik spline yang signifikan. Pengujian hipotesis untuk menguji signifikansi peubah secara parsial menggunakan hipotesis sebagai berikut:

$H_{0}: \hat{\beta}_{1}=0$ 
$H_{1}: \hat{\beta}_{h \neq 0 ; h=1,2, \ldots, 20}$

Berdasarkan Tabel 6 dapat diketahui bahwa 7 dari 21 parameter adalah signifikan dengan kriteria penolakan. Meski terdapat persamaan yang tak signifikan, lima peubah yang digunakan dianggap signifikan karena minimal dalam satu peubah terdapat satu parameter yang signifikan.

Sehingga peubah $\mathrm{X}_{1}, \mathrm{X}_{2}, \mathrm{X}_{3}, \mathrm{X}_{4}$, dan $\mathrm{X}_{5}$ memberikan pengaruh yang signifikan terhadap IPM di Provinsi Sulawesi Selatan.

Tabel 6 Hasil Pengujian Estimasi Peubah Secara Parsial

\begin{tabular}{|c|c|c|c|c|c|}
\hline Peubah & $\hat{\beta}$ & Estimasi & T_hitung & p-value & Ket \\
\hline & $\hat{\beta}_{0}$ & 3,06 & 1,94 & 0,86 & Tidak signifikan \\
\hline \multirow{4}{*}{$\mathrm{X} 1$} & $\hat{\beta}_{1}$ & 9,91 & 2,12 & 0,12 & Tidak signifikan \\
\hline & $\hat{\beta}_{2}$ & 6,79 & 5,54 & 0,01 & Signifikan \\
\hline & $\hat{\beta}_{3}$ & 6,84 & 2,63 & 0,079 & Tidak signifikan \\
\hline & $\hat{\beta}_{4}$ & $-7,23$ & $-7,53$ & 0,51 & Tidak signifikan \\
\hline \multirow{4}{*}{$\mathrm{X} 2$} & $\hat{\beta}_{5}$ & $-9,95$ & $-1,33$ & 0,28 & Tidak signifikan \\
\hline & $\hat{\beta}_{6}$ & 1,02 & 1,19 & 0,32 & Tidak signifikan \\
\hline & $\hat{\beta}_{7}$ & 3,21 & 5,04 & 1 & Tidak signifikan \\
\hline & $\hat{\beta}_{8}$ & 5,46 & 1,41 & 0,00 & Signifikan \\
\hline \multirow{4}{*}{$\mathrm{X} 3$} & $\hat{\beta}_{\mathrm{g}}$ & 5,50 & 3,34 & 0,04 & Signifikan \\
\hline & $\hat{\beta}_{1}$ & 8,59 & 4,99 & 0,02 & Signifikan \\
\hline & $\hat{\beta}_{1}$ & $-1,12$ & $-1,39$ & 0,26 & Tidak signifikan \\
\hline & $\hat{\beta}_{1}$ & 1,58 & 4,80 & 0,66 & Tidak signifikan \\
\hline \multirow{4}{*}{$\mathrm{X} 4$} & $\hat{\beta}_{1}$ & $-2,27$ & $-1,69$ & 0,88 & Tidak signifikan \\
\hline & $\hat{\beta}_{1}$ & 2,03 & 1,95 & 0,15 & Tidak signifikan \\
\hline & $\hat{\beta}_{1}$ & 0,00 & 0,00 & 1 & Tidak signifikan \\
\hline & $\hat{\beta}_{1}$ & $-4,05$ & $-3,97$ & 0,04 & Signifikan \\
\hline \multirow[b]{2}{*}{$\mathrm{X} 5$} & $\hat{\beta}_{1}$ & $-4,14$ & $-4,19$ & 0,02 & Signifikan \\
\hline & $\hat{\beta}_{1}$ & $-1,95$ & $-3,38$ & 0,04 & Signifikan \\
\hline
\end{tabular}




\begin{tabular}{|c|c|c|c|c|c|}
\hline Peubah & $\hat{\beta}$ & Estimasi & T_hitung & p-value & Ket \\
\hline \multirow{2}{*}{} & $\hat{\beta}_{1}$ & $-2,13$ & $-7,44$ & 0,99 & Tidak signifikan \\
\cline { 2 - 6 } & $\hat{\beta}_{2}$ & $-4,21$ & $-4,23$ & 0,97 & Tidak signifikan \\
\hline
\end{tabular}

Berdasarkan hasil analisis diatas adanya perbedaan dari hasil yang diberikan oleh uji parsial dengan uji Serentak biasanya disebabkan karena terjadinya kesalahan konfigurasi model sehingga meski secara individual, semua peubah bebas berpengaruh signifikan, namun secara simultan justru tidak menggambarkan peubah terikat dalam model, misalnya terdapat peubah bebas lain yang menjadi faktor kunci dari model, namun tidak terdapat dalam model.

\subsection{Pengujian Asumsi Residual}

Asumsi yang harus dipenuhi dalam pemodelan regresi nonparametrik spline adalah residual berdistribusi normal dan identik. Oleh karena itu dilakukan pengujian terhadap dua asumsi tersebut.

\subsubsection{Pengujian normalitas residual}

Uji normalitas digunakan untuk mengetahui apakah residual telah mengikuti pola distribusi normal. Pengujian normalitas yang digunakan menggunakan uji Kolmogorov-Smirnov.

Hipotesis yang digunakan adalah sebagai berikut:

$H_{0}$ : residual berdistribusi normal

$H_{1}$ : residual tidak berdistribusi normal

Hasil uji Kolmogorov-Smirnov disajikan dalam bentuk plot seperti terlihat pada Gambar 6.

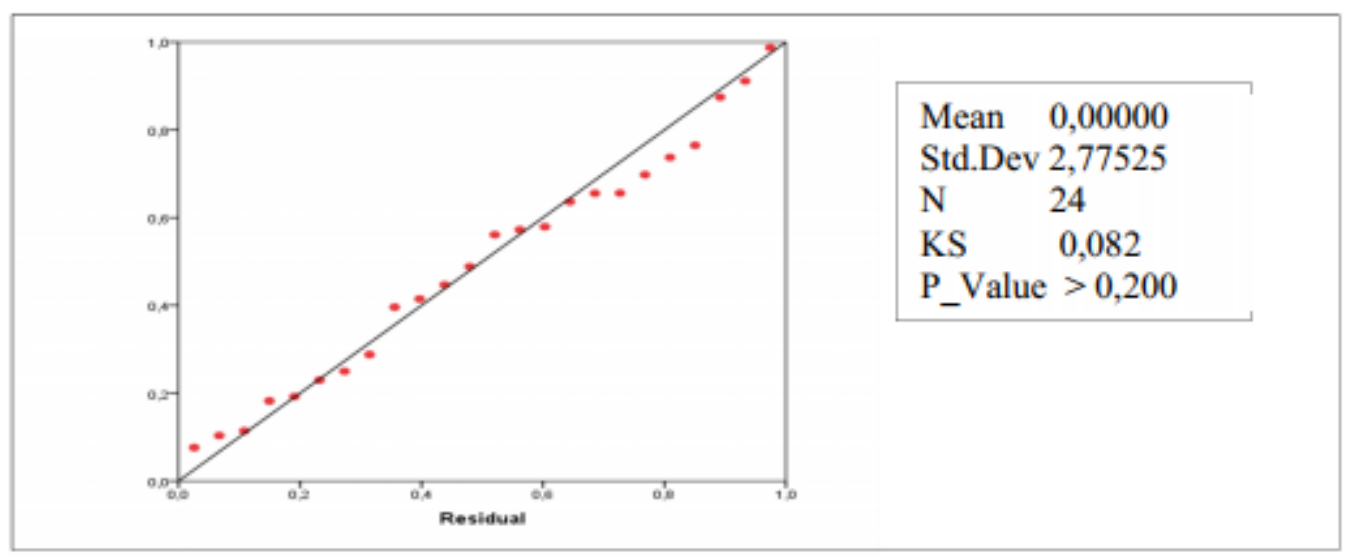

Gambar 6 Uji Normalitas Residual Kolmogorov-Smirnov

Berdasarkan Gambar 6 diperoleh nilai $P_{-}$Value $>0,200$ yang memiliki nilai lebih besar dari $=5 \%$ sehingga diperoleh keputusan gagal tolak H0 yang artinya bahwa residual mengikuti distribusi normal atau asumsi residual normal telah terpenuhi.

\subsubsection{Pengujian heteroskedastisitas}

Pengujian asumsi identik digunakan untuk mengetahui apakah varians residual telah homogen atau terjadi kasus heteroskedastisitas. Uji asumsi identik dilakukan menggunakan Uji Glejser. 
Hipotesis yang digunakan adalah sebagai berikut.

$$
\begin{aligned}
& H_{0}: \sigma_{1}^{2}=\sigma_{2}^{2} \ldots=\sigma_{2}^{2}=\sigma^{2} \\
& H_{1}: \text { minimal ada satu } \sigma_{i}^{2} \neq \sigma^{2} ; \quad i=1,2, \ldots, 20
\end{aligned}
$$

Adapun hasil uji asumsi identik dilakukan menggunakan Uji Glejser ditampilkan pada Tabel 7.

Tabel 7 Analisis Ragam Uji Glejser

\begin{tabular}{lrrrrc}
\hline $\begin{array}{l}\text { Sumber } \\
\text { Variasi }\end{array}$ & $(\mathbf{d b})$ & $(\mathbf{J K})$ & (RJK) & $\boldsymbol{F}_{\boldsymbol{H}}$ & $\boldsymbol{p}_{-} \boldsymbol{v}$ \\
\hline Regression & 20 & 419,43 & 20,97 & 0,61 & 0,79 \\
Residual & 3 & 102,96 & 34,32 & & \\
Total & 23 & 552,39 & & & \\
\hline
\end{tabular}

Berdasarkan Tabel 7 di dapatkan nilai $\mathrm{F}_{\mathrm{H}}$ dari uji Glejser sebesar 0,61 dengan p-value sebesar 0,79. Nilai p-value lebih besar dari $\alpha$ yang ditetapkan yaitu 0,05 sehingga keputusan yang diambil adalah gagal tolak $H_{0}$. Hal ini memberikan kesimpulan bahwa tidak terjadi kasus heteroskedastisitas atau asumsi residual identik telah terpenuhi.

\subsubsection{Koefisien Determinasi}

Nilai koefisien Determinasi $\left(\mathrm{R}^{2}\right)$ menunjukkan seberapa besar kebaikan model regresi dalam menjelaskan variabilitas angka IPM di Provinsi Sulawesi Selatan.

$$
\begin{aligned}
R^{2} & =\frac{S_{r}}{S_{t_{1}}} \times 100 \% \\
& =\frac{4 \quad, 4}{5,3} \times 100 \% \\
& =80,29 \%
\end{aligned}
$$

Berdasarkan perhitungan didapatkan $\mathrm{R}^{2}$ sebesar 80,29\%. Hal ini berarti model regresi nonparametrik spline yang didapatkan mampu menjelaskan variabilitas angka IPM di Provinsi Sulawesi Selatan sebesar 80,29\%. Nilai tersebut mendekati 100\%, sehingga model sudah cukup baik.

\subsection{Pembahasan}

\subsubsection{Karakteristik Penelitian}

Pembangunan manusia didefinisikan sebagai proses perluasan pilihan bagi penduduk. IPM merupakan indikator penting untuk mengukur keberhasilan dalam upaya membangun kualitas hidup manusia (masyarakat/penduduk). IPM menjelaskan bagaimana penduduk dapat mengakses hasil pembangunan dalam memperoleh pendapatan, kesehatan, pendidikan, dan sebagainya. IPM diperkenalkan oleh UNDP pada tahun 1990 dan metode penghitungan direvisi pada tahun 2010 .

Menurut UNDP, IPM mengukur pencapaian hasil pembangunan dari suatu daerah/wilayah dalam tiga dimensi dasar yaitu peluang hidup (longevity), pengetahuan (knowledge) dan standar hidup layak (living standars). Setiap tahunnya nilai IPM Sulawesi Selatan mengalami peningkatan. Pada tahun 2015 nilai IPM di Sulawesi Selatan tercatat 69,15 meningkat dibanding tahun sebelumnya yaitu sebesar 68,49.

Berdasarkan kategori IPM dari 24 kabupaten/kota di Provinsi Sulawesi Selatan, terdapat 19 Kabupaten yang masih berada di bawah kategori sedang yaitu Kabupaten Selayar, Bulukumba, Bantaeng, Jeneponto, Takalar, Gowa, Sinjai, 
Maros, Pangkep, Barru, Bone, Soppeng, Wajo, Sidrap, Pinrang, Luwu, Tana Toraja, Luwu Utara, dan Toraja Utara. Sedangkan untuk kategori IPM Tinggi terdapat 5 yang terdiri dari 3 Kabupaten dan 2 Kota yaitu Kabupaten Enrekang, Luwu Timur, Palopo, Kota Pare-pare dan Kota Makassar. Berdasarkan kategori IPM yang dikeluarkan oleh PBB, diketahui bahwa di Provinsi Sulawesi Selatan tahun 2015 nilai IPM yang terendah yaitu di Kabupaten Jeneponto sebesar 61,81 sedangkan nilai IPM tertinggi di Sulawesi Selatan berada pada Kota Makassar sebesar 79,94. Walaupun sebagian besar kabupaten/kota di Provinsi Sulawesi Selatan sudah berada dalam kategori tinggi, namun belum ada yang mampu menembus kategori sangat tinggi. Pemerintah Indonesia menargetkan nilai IPM untuk setiap provinsi yang ada di Indonesia berada pada kategori tinggi. Berdasarkan hal tersebut maka nilai IPM kabupaten/kota di Provinsi Sulawesi Selatan perlu ditingkatkan.

Berdasarkan analisis dari gambar Scatter plot di atas menunjukan bahwa dari lima peubah yaitu TPAK, RSM, kepadatan penduduk, fasilitas kesehatan, dan PDRB terhadap IPM memiliki pola hubungan yang tidak membentuk suatu pola tertentu, sehingga estimasi model yang digunakan adalah regresi nonparametrik.

\subsubsection{Interpretasi Model dari Indeks Pembangunan Manusia menggunakan Regresi Nonparametrik Spline}

Setelah dilakukan pengujian model regresi nonparametrik Spline dan semua asumsi residual terpenuhi, maka model regresi yang telah diperoleh tersebut dapat diinterpretasikan. Berdasarkan sub bab 4.6 diketahui bahwa nilai koefisien determinasi atau $\mathrm{R}^{2}$ dari model regresi nonparametrik spline yaitu 80,29\% dengan lima peubah yang signifikan yaitu TPAK, RSM, kepadatan penduduk, fasilitas kesehatan dan PDRB. Dengan nilai $R^{2}$ sebesar $80,29 \%$ dapat dikatakan bahwa model regresi nonparametrik Spline yang dihasilkan merupakan model yang baik dan layak digunakan untuk pemodelan.

Model regresi nonparametrik Spline yang terbentuk menggunakan titik knot optimal yakni tiga titik knot ditunjukkan pada persamaan berikut.

$$
\begin{aligned}
& \hat{y}=3,06+9,91 x_{1}+6,79\left(x_{1}-92,32\right)_{+}^{1}+6,84\left(x_{1}-103,21\right)_{+}^{1}- \\
& 7,23\left(x_{1}-538,72\right)_{+}^{1}-9,95 x_{2}+1,02\left(x_{2}-11,63\right)_{+}^{1}+3,21 \\
&\left(x_{2}-11,85\right)_{+}^{1}+5,46\left(x_{2}-21,37\right)_{+}^{1}+5,50 x_{3}+8,59 \\
&\left(x_{3}-542,41\right)_{+}^{1}-1,12\left(x_{3}-709,88\right)_{+}^{1}+1,58\left(x_{3}-7408,65\right)_{+}^{1} \\
&-2,27 x_{4}+2,03\left(x_{4}-81,84\right)_{+}^{1}+0,00\left(x_{4}-91,45\right)_{+}^{1}-4,05 \\
&\left(x_{4}-514,39\right)_{+}^{1}-4,13 x_{5}-1,95\left(x_{5}-7990,12\right)_{+}^{1}-2,13 \\
&\left(x_{5}-9745,56\right)_{+}^{1}-4,20\left(x_{5}-79963,03\right)_{+}^{1}
\end{aligned}
$$

Interpretasi model untuk peubah-peubah yang signifikan dilakukan untuk mengetahui pengaruhnya terhadap IPM. Adapun lima peubah yang signifikan yaitu TPAK, RSM, kepadatan penduduk, fasilitas kesehatan dan PDRB.

Berdasarkan model tersebut, maka dapat diinterpretasikan masing-masing peubah yang berpengaruh adalah sebagai berikut:

a. Apabila $\mathrm{X}_{2}, \mathrm{X}_{3}$, dan $\mathrm{X}_{4}, \mathrm{X}_{5}$ dianggap konstan, maka pengaruh TPAK $\left(\mathrm{X}_{1}\right)$ terhadap IPM adalah :

$$
\begin{aligned}
y= & 3,06+9,91 x_{1}+6,79\left(x_{1}-92,32\right)_{+}^{1}+6,84\left(x_{1}-103,21\right)_{+}^{1}- \\
7,23\left(x_{1}-538,72\right)_{+}^{1}-\mathrm{C} & \\
= & \left\{\begin{array}{ccc}
0,36+9,91 x_{1} & ; & x_{1}<92,32 \\
-626,49+16,7 x_{1} & ; & 92,32 \leq x_{1}<103,21 \\
-1332,45+23,54 x_{1} & ; & 103,21 \leq x_{1}<538,72 \\
3894,95+16,31 x_{1} & ; & x_{1} \geq 538,72
\end{array}\right.
\end{aligned}
$$


Berdasarkan model tersebut, apabila wilayah dengan TPAK kurang dari 92,32 naik sebesar satu \%, maka nilai IPM cenderung naik sebesar 9,91\%. Wilayah yang termasuk dalam kategori ini yaitu Kabupaten Selayar, Barru, Enrekang, Kota Parepare, dan Palopo. Apabila wilayah dengan tingkat TPAK berkisar antara 92,32 hingga 103,21 naik sebesar satu \%, maka IPM naik sebesar $16,7 \%$, wilayah yang termasuk dalam kategori ini yaitu Kabupaten Bantaeng, Soppeng, Enrekang, dan Toraja Utara. Apabila TPAK berkisar antara 103,21 hingga 538,72 naik sebesar satu \%, maka IPM cenderung naik sebesar 23,54 \%. Wilayah yang termasuh dalam kategori ini Kabupaten Bulukumba, Jeneponto, Takalar, Gowa, Sinjai, Maros, Pangkep, Bone, Wajo, Sidrap, Pinrang, Luwu, Tana Toraja, Luwu Utara, Luwu Timur dan Toraja Timur. Apabila TPAK lebih besar dari 538,72 naik sebesar satu \%, IPM cenderung naik sebesar 16,31\%. Wilayah yang termasuk kategori ini yaitu Kota Makassar.

b. Apabila $\mathrm{X}_{1}, \mathrm{X}_{3}$, dan $\mathrm{X}_{4}$, dianggap konstan, maka pengaruh RSM $\left(\mathrm{X}_{2}\right)$ terhadap IPM adalah :

$$
\begin{aligned}
\hat{y}= & 3,06+9,95 x_{2}+1,02\left(x_{2}-11,63\right)_{+}^{1}+3,21\left(x_{2}-11,85\right)_{+}^{1}+ \\
& 5,46\left(x_{2}-21,37\right)_{+}^{1}+\mathrm{C} \\
= & \left\{\begin{array}{ccc}
3,06+9,95 x_{2} & ; & x_{2}<11,63 \\
-8,80+10,97 x_{2} & ; & 11,63 \leq x_{2}<11,85 \\
-47,194+14,18 x_{2} & ; & 11,85 \leq x_{2}<21,37 \\
-163,87+19,64 x_{2} & ; & x_{2} \geq 21,37
\end{array}\right.
\end{aligned}
$$

Ketika angka RSM kurang dari 11,63 naik sebesar satu \%, maka IPM cenderung naik sebesar 9,95\%. Wilayah yang nilai yang masuk dalam kategori ini yaitu Kabupaten Jeneponto, Sinjai, Enrekang, Luwu Utara, dan Kota Palopo. Apabila RSM berkisar antara 11,63 hingga 11,85 naik sebesar satu \%, maka IPM cenderung naik sebesar $10,97 \%$, tidak ada wilayah yang nilai RSM masuk dalam kategori ini. Apabila RSM berkisar 11,85 hingga 21,37 naik sebesar 1\%, maka IPM cenderung naik sebesar 14,18 \%. Wilayah yang masuk dalam kategori ini yaitu Kabupaten Selayar, Bantaeng, Takalar, Gowa, Sinjai, Maros, Pangkep, Barru, Bone, Soppeng, Wajo, Sidrap, Pinrang, Enrekang, Luwu, Tana Toraja, Luwu Timur, Kota Makassar, dan Pare-pare. Apabila RSM lebih besar dari 21,37 naik sebesar satu \%, maka IPM cenderung naik sebesar 19,64\%. Wilayah yang nilai RSM masuk dalam kategori ini yaitu Kabupaten Bulukumba.

c. Apabila $\mathrm{X}_{1}, \mathrm{X}_{2}$, dan $\mathrm{X}_{4}$, dianggap konstan dianggap konstan, maka pengaruh Kepadatan Penduduk $\left(\mathrm{X}_{3}\right)$ terhadap indeks pembangunan manusia adalah:

$$
\begin{aligned}
& y= 3,06+5,50 x_{3}+8,59\left(x_{3}-542,41\right)_{+}^{1}-1,12\left(x_{3}-709,88\right)_{+}^{1}+ \\
& 1,58\left(x_{3}-7408,65\right)_{+}^{1}-C \\
&= \\
& \qquad \begin{array}{ccc}
3,06+5,50 x_{3} \quad ; & x_{3}<542,41 \\
-4656,24+14,09 x_{3} & ; & 542,41 \leq x_{3}<709,88 \\
-3861,17+12,97 x_{3} & ; & 709,88 \leq x_{3}<7408,65 \\
-15566,88+14,55 x_{3} & ; & x_{3} \geq 7408,65
\end{array}
\end{aligned}
$$

Ketika angka kepadatan penduduk kurang dari 542,41 naik sebesar 1\%, maka IPM cenderung naik sebesar 5,50 \%. Wilayah yang masuk dalam kategori ini yaitu Selayar, Bulukumba, Bantaeng, Jeneponto, Takalar, Gowa, Sinjai, Maros, Pangkep, Barru, Bone, Soppeng, Wajo, Sidrap, Pinrang, Enrekang, Luwu, Tana Toraja, Luwu Utara, dan Luwu Timur. Apabila kepadatan penduduk berkisar antara 542,41 hingga 709,88 naik sebesar satu \%, maka IPM cenderung naik sebesar 14,09\%. Wilayah yang termasuk dalam kategori ini yaitu Kota Palopo. Apabila kepadatan penduduk berkisar 709,88 hingga 7408,65 naik sebesar $1 \%$, maka IPM cenderung naik sebesar $12,97 \%$. Wilayah yang termasuk dalam kategori ini yaitu Kota Pare-pare. Apabih kepadatan penduduk lebih besar dari 7408,65 naik sebesar satu \%, maka IPM cenderung naik sebesar 14,55\%. Wilayah yang termasuk dalam kategori ini yaitu Kota Makassar. 
d. Apabila $\mathrm{X}_{1}, \mathrm{X}_{2}$, dan $\mathrm{X}_{3}$, dianggap konstan dianggap konstan, maka pengaruh Fasilitas Kesehatan $\left(\mathrm{X}_{4}\right)$ terhadap indeks pembangunan manusia adalah:

$$
\begin{aligned}
& \hat{y}=3,06-2,27 x_{4}+2,03\left(x_{4}-81,84\right)_{+}^{1}+0,00 \\
& \left(x_{4}-91,45\right)_{+}^{1}-4,05\left(x_{4}-514,39\right)_{+}^{1}-\mathrm{C} \\
& =\left\{\begin{array}{ccc}
3,06-2,27 x_{4} & ; & x_{4}<81,84 \\
-163,08-0,24 x_{4} & ; & 81,84 \leq x_{4}<91,45 \\
0-0,24 x_{4} & ; & 91,45 \leq x_{4}<514,39 \\
2083,28-4,29 x_{4} & ; & x_{4} \geq 514,39
\end{array}\right.
\end{aligned}
$$

Ketika nilai fasilitas kesehatan kurang dari 81,84 dan naik sebesar 1\%, maka IPM cenderung turun sebesar 2,27 $\%$. Wilayah yang masuk dalam kategori ini yaitu Kota Pare-pare. Apabila fasilitas kesehatan berkisar antara 81,84 hingga 91,45 naik sebesar satu \%, maka IPM cenderung turun sebesar 0,24 \%, tidak ada wilayah yang nilai fasilitas kesehatannya masuk dalam kategori ini. Apabila fasilitas kesehatan berkisar 91,45 hingga 514,39 naik sebesar $1 \%$, maka IPM cenderung turun sebesar 0,24 \%. Wilayah yang masuk dalam kategori ini yaitu Selayar, Bulukumba, Bantaeng, Jeneponto, Takalar, Gowa, Sinjai, Maros, Pangkep, Barru, Bone, Soppeng, Wajo, Sidrap, Pinrang, Enrekang, Luwu, Tana Toraja, Luwu Utara, Luwu Timur, kota Makassar dan Kota Palopo. Apabila fasilitas kesehatan lebih besar dari 514,39 naik sebesar satu \%, maka IPM cenderung turun sebesar 4,29 \%, tidak ada wilayah yang nilai fasilitas kesehatannya masuk dalam kategori ini.

e. Apabila $\mathrm{X}_{1}, \mathrm{X}_{2}$, dan $\mathrm{X}_{4}$, dianggap konstan dianggap konstan, maka pengaruh PDRB $\left(\mathrm{X}_{5}\right)$ terhadap indeks pembangunan manusia adalah:

$$
\begin{aligned}
y= & 3,06-4,13 x_{5}-1,95\left(x_{5}-7990,12\right)_{+}^{1}-2,13 \\
& \left(x_{5}-9745,56\right)_{+}^{1}-4,20\left(x_{5}-79963,03\right)_{+}^{1} \\
= & \left\{\begin{array}{ccc}
3,06-4,13 x_{5} \quad ; & x_{5}<7990,12 \\
15583,79-6,08 x_{5} & ; & 7990,12 \leq x_{5}<9745,56 \\
36341,83-8,21 x_{5} ; & 9745,56 \leq x_{5}<79963,03 \\
272186,56-12,41 x_{5} & ; & x_{5} \geq 79963,03
\end{array}\right.
\end{aligned}
$$

Ketika nilai PDRB kurang dari 7990,12 naik sebesar satu \%, maka IPM cenderung turun sebesar sebesar 4,13 $\%$. Wilayah yang masuk dalam kategori ini yaitu Selayar, Bulukumba, Bantaeng, Jeneponto, Takalar, Sinjai, Barru, Soppeng, Sidrap, Enrekang, Luwu,Tana Toraja, Luwu Utara, Kota Pare-pare dan Kota Palopo. Apabila PDRB berkisar antara 7990,12 hingga 9745,56 naik sebesar satu \%, maka IPM cenderung turun sebesar 6,08\%. Wilayah yang masuk dalam kategori ini yaitu Pinrang. Apabila PDRB berkisar 9745,56 hingga 79963,03 naik sebesar $1 \%$, maka IPM cenderung turun sebesar $8,21 \%$. Wilayah yang masuk dalam kategori ini yaitu Gowa, Maros, Pangkep, Bone, Wajo, dan Luwu Timur. Apabila PDRB lebih besar dari 79963,03 naik sebesar satu \%, maka IPM cenderung turun sebesar $12,41 \%$, Wilayah yang masuk dalam kategori ini yaitu Kota Makassar.

\section{Kesimpulan}

Berdasarkan hasil analisis dan pembahasan yang telah dilakukan, dapat disimpulkan beberapa hal sebagai berikut.

1. Pada tahun 2015 nilai IPM di Provinsi Sulawesi Selatan tercatat 69,15, meningkat dibanding tahun sebelumnya yaitu sebesar 68,49, menurut (BPS, 2016). Angka IPM tertinggi berada pada Kota Makassar sebesar 80,53, sedangkan IPM terendah berada pada Kabupaten Jeneponto sebesar 61,81. 
2. Model regresi nonparametrik spline untuk IPM kabupaten/kota di Provinsi Sulawesi Selatan diperoleh dari titik knot optimal menggunakan GCV minimum. Untuk pemilihan satu titik knot didapatkan nilai GCV minimum sebesar 30,91, dua titi knot dengan nilai GCV minimum sebesar 6,45, dan tiga titik knot dengan nilai GCV minimum sebesar 5,33. Dari ketiga knot tersebut nilai GCV yang paling optimal digunakan yaitu tiga titik knot dengan nilai GCV minimum sebesar 5,33. Nilai kebaikan model atau $\mathrm{R}^{2}$ yang diperoleh sebesar $80,29 \%$ dengan lima peubah yang signifikan. Berikut model regresi nonparametrik spline terbaik yang didapatkan:

$$
\begin{aligned}
\hat{y}=3,06 & +9,91 x_{1}+6,79\left(x_{1}-92,32\right)_{+}^{1}+6,84\left(x_{1}-103,21\right)_{+}^{1}- \\
& 7,23\left(x_{1}-538,72\right)_{+}^{1}-9,95 x_{2}+1,02\left(x_{2}-11,63\right)_{+}^{1}+3,21 \\
& \left(x_{2}-11,85\right)_{+}^{1}+5,46\left(x_{2}-21,37\right)_{+}^{1}+5,50 x_{3}+8,59 \\
& \left(x_{3}-542,41\right)_{+}^{1}-1,12\left(x_{3}-709,88\right)_{+}^{1}+1,58\left(x_{3}-7408,65\right)_{+}^{1} \\
& -2,27 x_{4}+2,03\left(x_{4}-81,84\right)_{+}^{1}+0,00\left(x_{4}-91,45\right)_{+}^{1}-4,05 \\
& \left(x_{4}-514,39\right)_{+}^{1}-4,13 x_{5}-1,95\left(x_{5}-7990,12\right)_{+}^{1}-2,13 \\
& \left(x_{5}-9745,56\right)_{+}^{1}-4,20\left(x_{5}-79963,03\right)_{+}^{1}
\end{aligned}
$$

3. Berdasarkan hasil analisis diperoleh bahwa faktor-faktor yang berpengaruh secara signifikan terhadap IPM kabupaten/kota di Provinsi Sulawesi Selatan adalah TPAK, RSM, Kepadatan Penduduk, Fasilitas Kesehatan dan PDRB.

\section{References}

BPS. (2016). Indeks Pembangunan Manusia 2010-2014.

BPS. (2016). Indeks Pembangunan Manusia 2015.

Budiantara, I. N. (2009). Spline dalam Regresi Nonparametrik dan Semiparametrik: Sebuah Pemodelan Statistika Masa Kini dan Masa Mendatang. Surabaya : Institut Teknologi Sepuluh Nopember.

Demu, K. R, Saputra, D. S. \& Widyaningsi, P. (2017), Model Regresi Nonparametrik Truncated pada data Indeks Pembangunan Manusia (IPM). Surabaya : Institut Teknologi Sepuluh Nopember.

Draper, N. R. \& Smith, H. (1992). Analisis Regresi Terapan, Diterjemahkan oleh: Bambang Sumantri, Jakarta: Gramedia Pustaka Utama.

Eubank, R. (1988). Spline Smoothing and Nonparametric Regression. New York: Marcel Dekker.

Fajriyah, Nurul. \& Budiantara, I. N. (2015). Pemodelan Indeks Pembangunan Gender dengan Pendekatan Regresi Nonparametrik Spline di Indonesia. Jurnal Sains dan Seni ITS (Nomor 2 Vol 4). Surabaya: Institut Teknologi Sepuluh Nopember.

Hardle, W. (1990). Applied Nonparametric Regression, Cambridge University Press, New York.

Nafi, M. \& Budiantara, I. N. (t,thn,). Estimasi interval spline dalam regresi nonparametrik. Surabaya: Institut Teknologi Sepuluh Nopember.

Respita, R. D. (2017). Perbandingan model regresi spline dan multivariate adaptive regression splines untuk analisis survival pada pasien kanker serviks di RSUD DR.Soetomo Surabaya. Tesis. Surabaya: Institut Teknologi Sepuluh Nopember. United Nations Development Programme. (1993). Human Development Report, New York: UNDP. 
Wahba, G. (1990). Spline Models For Observasion Data, SIAM. Pensylvania. Wulandari, Krisna. (2017). Pemodelan Faktor-Faktor Yang Mempengaruhi Angka Morbiditas Di Jawa Timur Menggunakan Regresi Nonparametrik Spline. Tesis. Surabaya: Institut Teknologi Sepuluh Nopember.

Yanthi, N. D. \& Budiantara, I. N. (2016). Pemodelan Faktor-faktor yang Mempengaruhi Indeks Pembangunan Manusia Menggunakan Regresi Nonparametrik Spline di Jawa Tengah. JURNAL SAINS DAN SENI ITS, 2337-3520. 